\title{
Study on Mechanical Properties and Control Technology of Surrounding Rock in the Fracture Zone of a Roadway
}

\author{
Yushun Yang $\mathbb{D},{ }^{1,2}$ Zhiming Fang $\mathbb{D},{ }^{3}$ Guangying $J i\left(\mathbb{D},{ }^{3}\right.$ Baigao Zhao $\mathbb{i},{ }^{3}$ and Sijiang Wei $\mathbb{i D}^{4}$ \\ ${ }^{1}$ Faculty of Architecture and Civil Engineering, Huaiyin Institute of Technology, Huai'an 223001, Jiangsu, China \\ ${ }^{2}$ State and Local Joint Engineering Laboratory for Gas Drainage \& Ground Control of Deep Mines, Henan Polytechnic University, \\ Jiaozuo, China \\ ${ }^{3}$ Xinyi Mine Co., Ltd., Jining, Shandong, China \\ ${ }^{4}$ School of Energy Science and Engineering, Henan Polytechnic University, Jiaozuo 454003, Henan, China
}

Correspondence should be addressed to Yushun Yang; cqyysh@126.com

Received 13 October 2020; Revised 6 November 2020; Accepted 23 December 2020; Published 12 January 2021

Academic Editor: Guangchao Zhang

Copyright ( $) 2021$ Yushun Yang et al. This is an open access article distributed under the Creative Commons Attribution License, which permits unrestricted use, distribution, and reproduction in any medium, provided the original work is properly cited.

\begin{abstract}
We aim at the problem of the large deformation and difficult control of surrounding rock when passing through a fault fracture zone in the centralized rail transportation lane along the south wing of Xinyi Coal Mine; the stress environment and failure mechanism of surrounding rock are analyzed through field investigation, numerical simulation, and field industrial test. The instability of the surrounding rock in the fault fracture zone was considered to be the result of the joint effect of the surrounding rock fracture development, lithology differences, water gushing occurrences, low strength of the original support, high in situ stress, and fault-related tectonic stress. Rock blocks are collected on site at the fracture zone, and the remoulded samples are prepared for mechanical experiments in the laboratory. The basic mechanical parameters of the roadway passing through silty mudstone, sand-mudstone interlayer, and fine sandstone were analyzed. A three-dimensional model is established to analyze the distributions of the stress, deformation, and plastic area in the surrounding rock mass after the tunnel passes through, considering both a single-rock mass and a multilayer-rock mass. Based on the above analysis, the "closed support + shotcrete + grouting + anchor mesh cable coupling support" is proposed. Three stations were arranged on site to observe the mine pressure, and the field industrial test shows that, within the 100 days of observation, the maximum roof-to-floor convergence is $38 \mathrm{~mm}$, while the maximum horizontal convergence is $56 \mathrm{~mm}$. The overall reinforcement effect of the roadway is good, the surface is smooth, and there is no phenomenon of concrete cracking and bolt fracture.
\end{abstract}

\section{Introduction}

In the process of coal mine roadway driving, it is often encountered with fault and fracture zone and other unfavorable geological strata, which have the characteristics of structural development, low strength, high water permeability, easy deformation, and other soft rocks. The bearing capacity of the rock mass in the fault fracture zone is weak, the lithology is complex, the support is difficult, the stress distribution in the fault fracture zone is complex, and the mine pressure law is variable, which seriously threatens the safety of the construction process.

At present, scholars at home and abroad have done a lot of research on the surrounding rock support of the roadway in the fault fracture zone and achieved some results [1-4].
Zhang et al. [5] studied the construction geological guarantee and surrounding rock control technology of the roadway in the super large fault area based on the engineering background of the safe excavation of the main transport roadway passing through the fault zone. Xiao et al. [6] studied the rule of the influence of fault zone on the mining roadway through the method of experiment and numerical calculation, which provided the basis for the reasonable arrangement and effective control of the roadway near the fault. Zhao et al. [7] summarized the application experience of the advanced pipe shed grouting support technology in the roadway support by studying the deformation control of the broken surrounding rock when the roadway passes through the complex fault zone. Wang et al. [8] used the yielding type anchor cable box girder support 
system in the fault area of the coal roadway to realize "control first, then resistance," which not only played the role of the support system but also gave full play to the selfbearing capacity of the surrounding rock. Hao et al. [9] put forward the control measures of blot + mesh + anchor supporting measures to realize supports with strength, stiffness, and the structure, so as to achieve the stability control in deep soft roadway excavation. Zhang [10] put forward the support principle of "two high and one large" in view of the large deformation of the fault broken coal and rock roadway. Yan et al. [11] studied the surrounding rock control technology of the roadway in the fault area on the aquifer and proposed that "advance grouting, shotcreting and anchoring grouting stage reinforcement is the foundation support, and then the key parts of anchor cable reinforcement and surrounding rock grouting technology are implemented." Meng et al. [12] put forward the technical scheme of "primary steel mesh spraying + reinforced concrete lining + secondary grouting" combined support for the difficult problem of roadway passing through faults under complex geological conditions. Song et al. [13] used the theory of ultralow friction effect of rock mass and the theory of dynamic load stress wave to study the influence of dynamic load on fault fracture zone and put forward the corresponding safety measures of roadway passing through fault. In view of the floor heave problem in the south wing area of Yangcheng Coal Mine, Wang et al. [14] proposed to optimize the full-face support by adopting the support technology of bolt mesh shotcrete and concrete filled steel tube. Kang et al. [15] analyzed the deformation characteristics of surrounding rock of roadway in ultra-kilometer-deep mine and put forward supporting measures. Jia and Wang [16] analyzed the deformation and failure mechanism of weak surrounding rock and proposed a buffering gradual change type double strength shell support method suitable for soft rheological rock mass. Meng et al. [17] analyzed the distribution characteristics of surrounding rock support stress field caused by anchor bolt and anchor cable under different preload and spacing and proposed a step-by-step combined support scheme of bolt mesh cable spraying + U-shaped steel support + grouting + floor bolt grouting for soft rock roadway. He and Zhang [18] aimed at the problem of surrounding rock stability control of deep broken soft rock roadway and proposed a multilevel bolt shotcrete combined support system with high-strength bolt dense support, new spray layer structure surface protection, and lag grouting reinforcement. Li et al. [19] studied the relationship between the failure area of circular roadway, residual strength of stratum, and support pressure in isotropic homogeneous stratum. The above research has carried on the correlation research to the tunnel passing through the fault instability mechanism and the control technology, but, to the tunnel passing through the fault and the weak rock zone surrounding rock instability mechanism and the control technology that still needs to be further explored, especially to the fault fracture zone surrounding rock mechanical characteristic, researches are few.

Based on the previous research results and methods, aiming at the problems of large deformation and difficult control of surrounding rock when passing through the fault fracture zone and soft rock zone in the driving process of the centralized rail transport roadway in the south wing of Xinyi Coal Mine, this paper puts forward the methods of field investigation, laboratory mechanical test, numerical simulation, and theoretical analysis to analyze the instability mechanism of surrounding rock in the fracture zone and puts forward that the form of "closed support + shotcrete + grouting + anchor mesh cable coupling support" is introduced, and the industrial test is carried out in the field.

\section{Engineering Background}

Xinyi Coal Mine is located in the northwest of Yanzhou City, Shandong Province, China. The mining area is about $4 \mathrm{~km}$ long in the northwest and $4 \mathrm{~km}$ wide in the northeast with an area of about $11.7 \mathrm{~km}^{2}$. The surface topography of the mining area is flat, and there are no rivers or lakes on the surface of the mining area. The ground elevation is $47.0 \sim 50.0 \mathrm{~m}$. The faults in the mine field are relatively developed, mainly tensile, and torsional normal faults, and most of them strike NNE or NE. The excavation of Xinyi Coal Mine's south wing centralized rail transportation lane passed through three faults, and the strata are soft rock layers such as silty mudstone, sandy mudstone, and fine sandstone. The fractures of the fault fracture zone in the surrounding rock are developed, and there is angular sand gushing out from the fault, which has a great impact on the stability of the surrounding rock of the roadway. The thickness of the silty mudstone is $11 \mathrm{~m}$, and the silty mudstone is easily broken into pieces by hard objects. The main component of the silty mudstone is clay minerals, with a small amount of silty sand. After one month of anchor mesh support in the early stage of excavation, the roadway has obvious section shrinkage, and the roof subsidence is serious, as shown in Figure 1(a).

The thickness of the interbedded sandstone-mudstone layer is $12 \mathrm{~m}$, and this layer is composed of a large number of light green grey mudstones mixed in siltstone, with horizontal bedding, which is easily broken into pieces in the roadway. After excavation and disturbance, the cracks develop and expand when encountering water. The deformation of the roof is large, and there is a net pocket phenomenon. The anchoring force of the anchor bolt used for support in the early stage is seriously relaxed, as shown in Figure 1(b). The thickness of the fine sandstone is $14 \mathrm{~m}$, and the fine sandstone is light grey, with quartz, feldspar, and calcic argillaceous cementation. Although the strength of fine sandstone is high, its integrity is greatly damaged due to being in the fault fracture zone. Compared with the silty mudstone and sandy mud interbedded roadways, the mine pressure is not particularly obvious, and the roadway deformation is small under the early support, as shown in Figure 1(c).

\section{Physical and Mechanical Experiment of Rock}

3.1. Sample Preparation. Because the fractures of the interbedded silty mudstone and sand mudstone are well developed, the degree of cementation is loose, and the rock is easily weathered and disintegrated, softens rapidly when 

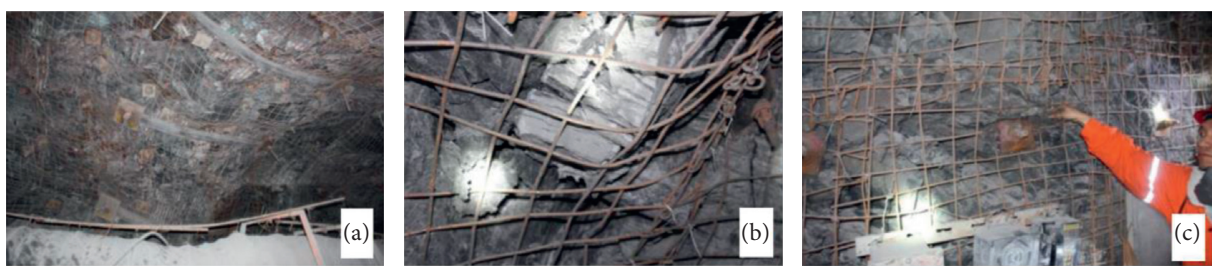

Figure 1: Roadway damage.

encountering water, and was argillized; thus, it is difficult to process it into standard samples. Therefore, in this paper, the rock samples with developed fractures are processed into remoulded samples meeting the rock mechanics experimental standard. The denser and harder fine sandstone can be processed directly into standard samples.

(1) Fine sandstone sample. Intact rock blocks with a size of approximately $200 \mathrm{~mm} \times 200 \mathrm{~mm} \times 200 \mathrm{~mm}$ were collected on site and transported back to the laboratory for processing into eight standard cylindrical samples with a size of $\varphi 50 \times 100 \mathrm{~mm}$ (three uniaxial compression samples $\mathrm{C}_{1} \sim \mathrm{C}_{3}$ and five triaxial compression samples $\mathrm{C}_{4} \sim \mathrm{C}_{8}$ ) and three Brazilian split samples with a size of $\varphi 50 \times 25 \mathrm{~mm}\left(\mathrm{C}_{9} \sim \mathrm{C}_{11}\right)$.

(2) Remoulded sample of silty mudstone and sandmudstone interlayer. The preparation method is as follows: crush the original rock samples collected on site into crushed stone with a particle size of $50 \mathrm{~mm}$; grind in a ball mill for $3 \mathrm{~min}$, and filter the rock powder with a 200-mesh sieve; weigh the rock powder pass $M$, and add $5 \% M$ of rock powder to water and stir uniformly; put the mixture into the mould and stabilize it for $30 \mathrm{~min}$ with an axial pressure of $200 \mathrm{kN}$ on a press; take out the samples to determine the compression ratio, make a standard reshaped sample, and dry the samples. Among them, there are eight remoulded silty mudstone samples (three uniaxial compression samples $A_{1}-A_{3}$ and five triaxial compression samples $\mathrm{A}_{4}-\mathrm{A}_{8}$ ) and Brazilian split samples of $\varphi 50 \times 25 \mathrm{~mm}$ (a total of three samples $\mathrm{A}_{9}-\mathrm{A}_{11}$ ). There are a total of eight remoulded sandstone-mudstone interbedded rock samples (three uniaxial compression samples $B_{1}-B_{3}$ and five triaxial compression samples $\mathrm{B}_{4}-\mathrm{B}_{8}$ ) and Brazilian split samples of $\varphi 50 \times 25 \mathrm{~mm}$ (a total of three samples $\left.\mathrm{B}_{9}-\mathrm{B}_{11}\right)$. A prepared partially remoulded sample is shown in Figure 2.

\subsection{Test Design}

(1) Brazilian splitting test: Displacement control (at a rate of $0.05 \mathrm{~mm} / \mathrm{s}$ ) is used to apply load to the specimen.

(2) Uniaxial compression test: Displacement control (at a rate of $0.1 \mathrm{~mm} / \mathrm{s}$ ) is used to apply axial pressure to the specimen.

(3) Triaxial compression test: (1) For the fine-sandstone sample, axial pressure and confining pressure are gradually applied to the hydrostatic pressure $\sigma_{1}=\sigma_{2}$ $\left(\sigma_{3}\right)=5 \mathrm{MPa}$, and the constant confining pressure remains unchanged, using displacement control (at a rate of $0.1 \mathrm{~mm} / \mathrm{s}$ ) to apply an axial pressure until the sample is destroyed. At the end of the test, the rock sample is replaced, and the confining pressure is changed to $5 \mathrm{MPa}, 10 \mathrm{MPa}, 15 \mathrm{MPa}, 20 \mathrm{MPa}$, and $25 \mathrm{MPa}$. (2) For the remoulded sample of silty mudstone and sand-mudstone interlayer, the axial pressure and confining pressure are gradually applied to the hydrostatic pressure $\sigma_{1}=\sigma_{2}\left(\sigma_{3}\right)=2 \mathrm{MPa}$, and the constant confining pressure remains unchanged. Displacement control (at a rate of $0.1 \mathrm{~mm} /$ s) is used to apply the axial pressure until sample failure, the rock sample is replaced, and the confining pressure is changed to $2 \mathrm{MPa}, 3 \mathrm{MPa}, 4 \mathrm{MPa}, 5 \mathrm{MPa}$, and $6 \mathrm{MPa}$, respectively.

3.3. Test Equipment. The test of the mechanical parameters of the sample adopts the RMT-150B electrohydraulic servo test system developed by the Institute of Rock and Soil Mechanics, Chinese Academy of Sciences, as shown in Figure 3. The test system has a maximum axial load of $1000 \mathrm{kN}$, a maximum horizontal load of $500 \mathrm{kN}$, and a maximum confining pressure of $50 \mathrm{MPa}$. It can perform rock tests such as uniaxial compression, indirect (direct) tension, compression shear, and triaxial compression. It can adopt various control modes of load, displacement, and stroke. During the test, a computer automatically collects the load and deformation data and displays them in real time.

\subsection{Analysis of Rock Sample Results}

3.4.1. Analysis of Brazilian Split Test Results. The basic principle of Brazilian splitting is based on the elastic theoretical solution of a disk subjected to diametral compression. The maximum tensile stress acting on the centre of the sample when the sample is damaged is

$$
\sigma_{t}=\frac{2 P}{\pi D h}
$$

where $\sigma_{t}$ is the maximum tensile stress in the centre of the sample, which is the tensile strength, $\mathrm{Pa} ; P$ is the ultimate pressure when the sample is damaged, $N$; and $D$ and $h$ are the diameter and thickness of the pressure disc, respectively, $\mathrm{mm}$.

According to the basic parameters and test results of the sample, the tensile strength of the sample can be calculated 


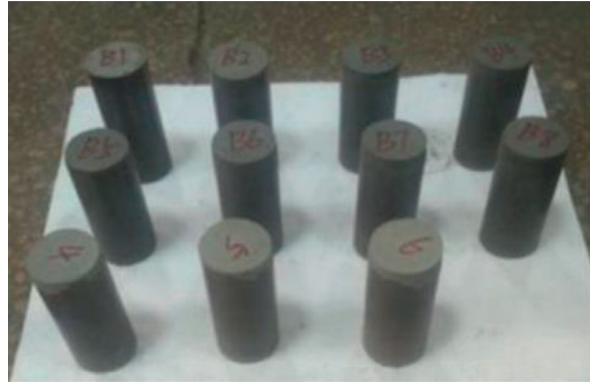

(a)

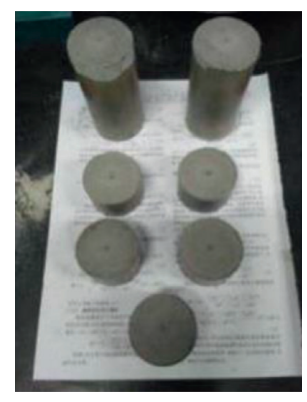

(b)

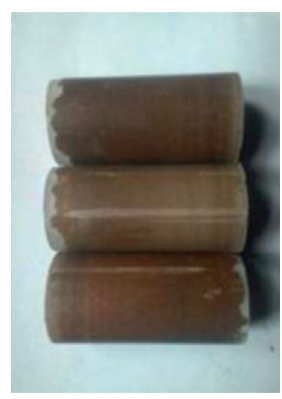

(c)

Figure 2: Prepared partially remoulded specimen.

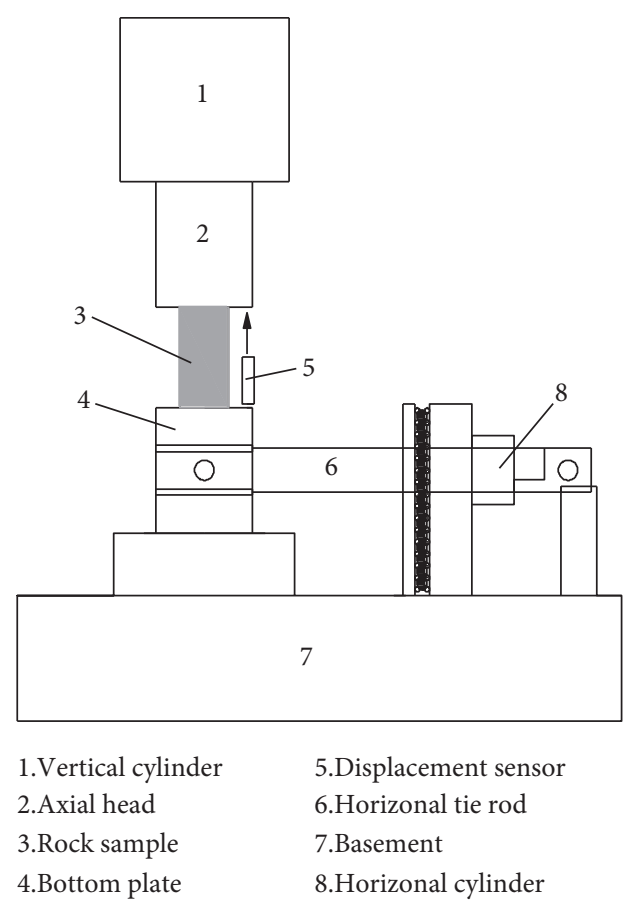

(a)

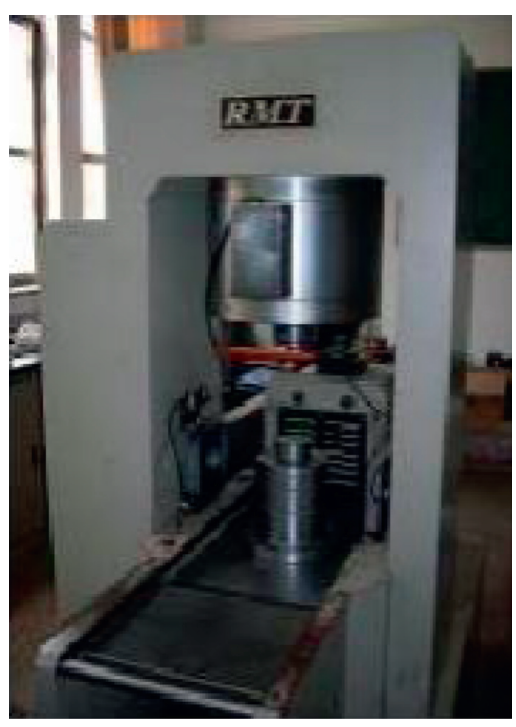

(b)

FIGURE 3: RMT-150B rock electrohydraulic servo test system.

from formula (1), as shown in Table 1. The average tensile strength of the silty mudstone is approximately $1.44 \mathrm{MPa}$, the average tensile strength of the sandstone mudstone interlayer is approximately $1.61 \mathrm{MPa}$, and the average tensile strength of the fine sandstone is approximately 3.70 MPa.

3.4.2. Analysis of Uniaxial Compression Test Results. The compressive strength of each sample is obtained from the complete stress-strain curve of each sample after uniaxial compression, and the elastic modulus and Poisson's ratio of each sample are calculated, as shown in Table 2. According to Table 2, the average uniaxial compressive strength of a siltymudstone remoulded sample is $13.86 \mathrm{GPa}$, the average elastic modulus is $1.48 \mathrm{GPa}$, and the average Poisson's ratio is 0.14 . The average uniaxial compressive strength of the sandmudstone interlayer remoulded sample is $12.28 \mathrm{MPa}$, the average elastic modulus is $1.54 \mathrm{GPa}$, and the average Poisson's ratio is 0.09 . The average uniaxial compressive strength of a fine-sandstone sample is $74.20 \mathrm{MPa}$, the average elastic modulus is $6.74 \mathrm{GPa}$, and the average Poisson's ratio is 0.23 .

According to the mass, diameter, and height of each sample (Table 2), it can be calculated that the density of a silty-mudstone sample is $2190 \mathrm{~kg} / \mathrm{m}^{3}$, the density of a sandmudstone interlayer sample is $2197 \mathrm{~kg} / \mathrm{m}^{3}$, and the density of a fine-sandstone sample is $2486 \mathrm{~kg} / \mathrm{m}^{3}$.

3.4.3. Analysis of Triaxial Compression Results. According to the complete stress-strain curve of each sample after triaxial compression, the compressive strength of each sample under different confining pressures is obtained, as shown in Tables 3 and 4 .

In the field of rock mass engineering, the pseudotriaxial compression failure of rock conforms to the Mohr-Coulomb strength criterion, as shown in Figure 4(a). The Mohr- 
TABLE 1: Physical and mechanical parameters of each specimen.

\begin{tabular}{|c|c|c|c|c|c|c|}
\hline Name & No. & Mass (g) & Length (mm) & Diameter $(\mathrm{mm})$ & Tensile strength $(\mathrm{MPa})$ & Average value (MPa) \\
\hline \multirow{3}{*}{ Silty mudstone } & $>A_{9}$ & 141.9 & 34.1 & 49.4 & 1.43 & \multirow{3}{*}{1.44} \\
\hline & $\mathrm{A}_{10}$ & 149.3 & 34.3 & 49.4 & 1.48 & \\
\hline & $\mathrm{A}_{11}$ & 148.0 & 34.1 & 49.4 & 1.40 & \\
\hline \multirow{3}{*}{ Sand-mudstone interlayer } & $\mathrm{B}_{9}$ & 115.6 & 27.1 & 49.4 & 1.51 & \multirow{3}{*}{1.61} \\
\hline & $\mathrm{B}_{10}$ & 116.3 & 26.8 & 49.4 & 1.64 & \\
\hline & $\mathrm{B}_{11}$ & 115.3 & 26.9 & 49.4 & 1.68 & \\
\hline \multirow{3}{*}{ Fine sandstone } & $\mathrm{C}_{9}$ & 126.1 & 26.8 & 49.4 & 3.76 & \multirow{3}{*}{3.70} \\
\hline & $\mathrm{C}_{10}$ & 125.0 & 26.5 & 49.4 & 3.84 & \\
\hline & $\mathrm{C}_{11}$ & 124.7 & 26.4 & 49.5 & 3.48 & \\
\hline
\end{tabular}

TABle 2: Physical and mechanical parameters of each specimen.

\begin{tabular}{|c|c|c|c|c|c|c|c|}
\hline Name & No. & $\begin{array}{c}\text { Mass } \\
(\mathrm{g})\end{array}$ & $\begin{array}{l}\text { Length } \\
(\mathrm{mm})\end{array}$ & $\begin{array}{l}\text { Diameter } \\
(\mathrm{mm})\end{array}$ & $\begin{array}{c}\text { Compressive strength } \\
(\mathrm{MPa})\end{array}$ & $\begin{array}{c}\text { Elastic modulus } \\
(\mathrm{GPa})\end{array}$ & $\begin{array}{l}\text { Poisson's } \\
\text { ratio }\end{array}$ \\
\hline \multirow{3}{*}{ Silty mudstone } & $\mathrm{A} 1$ & 433.7 & 101.0 & 49.4 & 14.516 & 1.416 & 0.191 \\
\hline & $\mathrm{A} 2$ & 433.2 & 101.5 & 49.4 & 12.737 & 1.373 & 0.024 \\
\hline & A3 & 432.1 & 102.6 & 49.4 & 14.322 & 1.655 & 0.199 \\
\hline \multirow{3}{*}{$\begin{array}{l}\text { Sand-mudstone } \\
\text { interlayer }\end{array}$} & $\mathrm{B} 1$ & 456.3 & 107.7 & 49.4 & 12.726 & 1.376 & 0.098 \\
\hline & $\mathrm{B} 2$ & 429.2 & 102.2 & 49.4 & 11.334 & 1.618 & 0.075 \\
\hline & B3 & 424.8 & 101.1 & 49.4 & 12.782 & 1.615 & 0.103 \\
\hline \multirow{3}{*}{ Fine sandstone } & $\mathrm{C} 1$ & 465.3 & 97.1 & 49.3 & 76.442 & 7.195 & 0.13 \\
\hline & $\mathrm{C} 2$ & 474.5 & 100.0 & 49.4 & 71.928 & 6.173 & 0.306 \\
\hline & $\mathrm{C} 3$ & 476.1 & 100.1 & 49.5 & 74.244 & 6.841 & 0.263 \\
\hline
\end{tabular}

TABLE 3: Triaxial compression test results of remoulded specimens under different confining pressure.

\begin{tabular}{lccccccc}
\hline \multirow{2}{*}{ Name } & \multicolumn{4}{c}{ Confining pressure $(\mathrm{MPa})$} & \multicolumn{2}{c}{ Internal friction angle $\left(^{\circ}\right)$} & Cohesion $(\mathrm{MPa})$ \\
& 2 & 3 & 4 & 5 & 6 & 41.98 & 3.12 \\
Silty mudstone & 22.96 & 28.95 & 33.52 & 38.56 & 44.43 & 44.42 & 2.91 \\
Sand-mudstone interlayer & 23.78 & 30.54 & 36.84 & 41.59 & 46.54 & \\
\hline
\end{tabular}

TABLe 4: Triaxial compression test results of fine sandstone specimens under different confining pressures.

\begin{tabular}{lccccccc}
\hline \multirow{2}{*}{ Name } & \multicolumn{4}{c}{ Confining pressure $(\mathrm{MPa})$} & \multicolumn{2}{c}{ Internal friction angle $\left(^{\circ}\right)$} & \multirow{2}{*}{ Cohesion $(\mathrm{MPa})$} \\
& 5 & 10 & 15 & 20 & 25 & 31.5 \\
\hline Fine sandstone & 94.842 & 114.118 & 127.316 & 143.835 & 159.737 & 22.45 \\
\hline
\end{tabular}

Coulomb strength criterion is widely used for rock under the action of compressive stress. The criterion considers that failure occurs when the shear stress $\tau$ at a point in the rock mass reaches the limit stress $\tau_{s}$, and the expression is shown in formula:

$$
\tau_{s}=c+\sigma \tan \varphi
$$

where $\sigma$ is the normal stress, $c$ is the cohesion, and $\varphi$ is the internal friction angle.

The maximum principal stress $\sigma_{s}$ and the minimum principal stress $\sigma_{c}$ have a linear relationship [20], as shown in Figure $4(\mathrm{~b})$, and the expression is shown as follows:

$$
\sigma_{s}=k \sigma_{3}+\sigma_{c}
$$

where $\sigma_{c}$ is the uniaxial compressive strength, $\mathrm{MPa} k$ is the slope of the strength envelope, $k=\tan ^{2}\left(45^{\circ}+(\varphi / 2)\right) ; \varphi$ is the internal friction angle.
According to formulas (2) and (3), Mohr's circle and envelope of the silty-mudstone remoulded samples, sandmudstone interlayer remoulded samples, and fine-sandstone samples are plotted, as shown in Figure 5, and then the internal friction angle and cohesion value of the three samples are calculated, as shown in Tables 3 and 4 .

Through the observation of the rock mass characteristics of the strata that the roadway passes through during the development process, the GSI (Geological Strength Index) engineering rock mass classification is used to evaluate the rock mass via the quantitative value of GSI [21], as shown in Table 5.

Then classify the surrounding rock masses of the south wing track uphill, so as to divide the surrounding rock types of the south wing centralized track transportation lane into three categories: silty mudstone (category V, integrity coefficient 0.15 ), sand-mudstone interlayer (category IV, integrity coefficient 0.35 ), and fine sandstone (category III, integrity coefficient 0.55 ). 


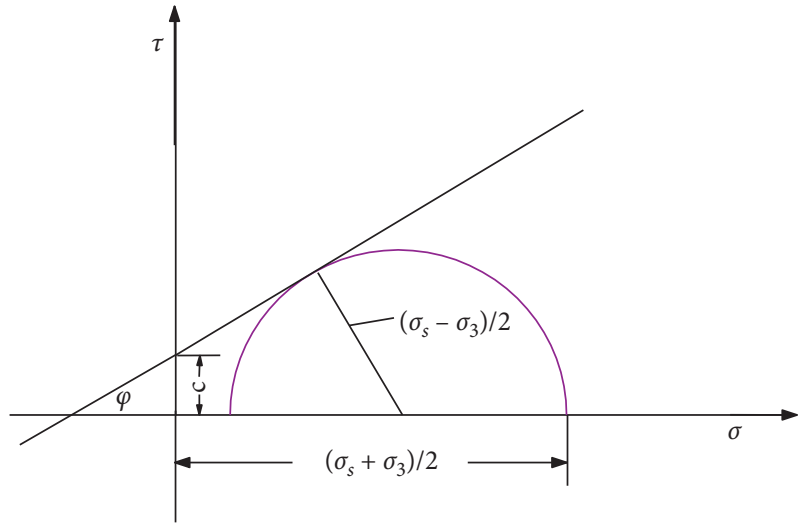

(a)

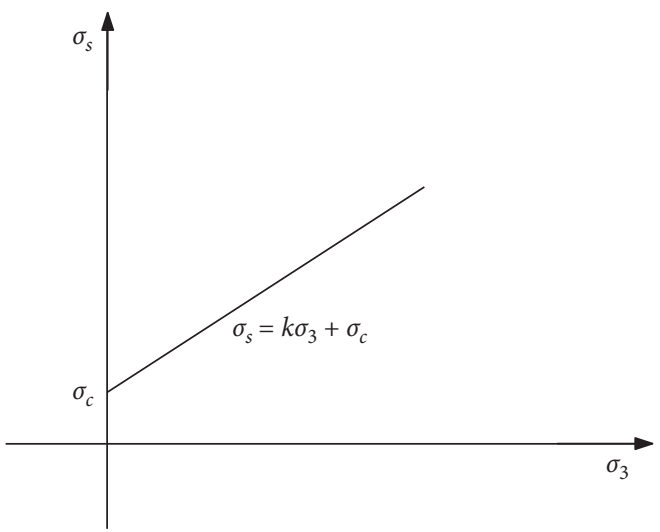

(b)

Figure 4: Mohr-Coulomb strength criterion and stress curve at failure. (a) Mohr-Coulomb strength criterion. (b) Stress curve at failure.

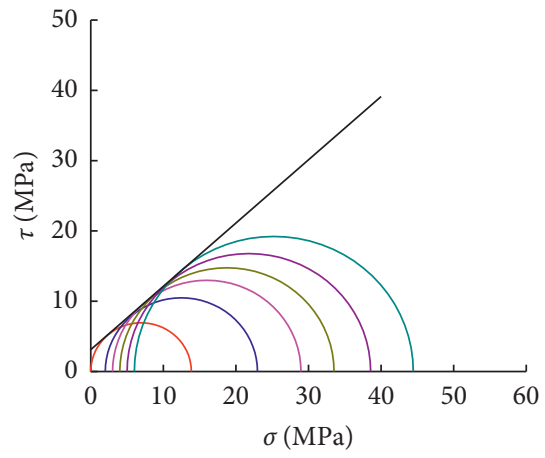

(a)

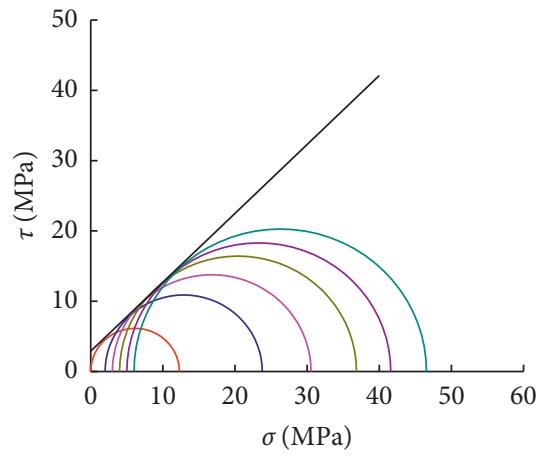

(b)

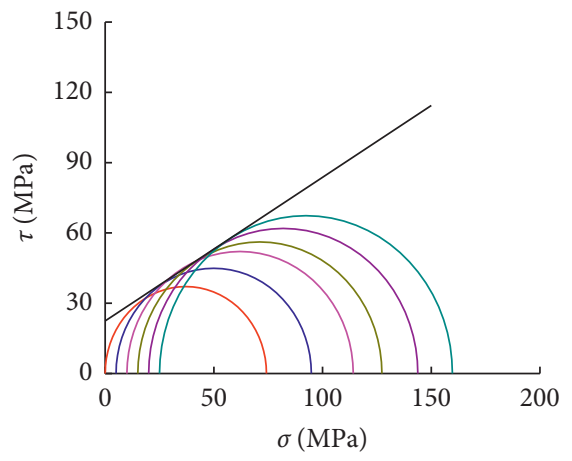

(c)

Figure 5: Mohr stress circle and envelope of each type of different surrounding rock. (a) Silty mudstone. (b) Sand-mudstone interlayer. (c) Fine sandstone.

TABLE 5: Types and integrity coefficients of the surrounding rock in the fault zone.

\begin{tabular}{lccc}
\hline Name & Integrity coefficient & GSI score & Category \\
\hline Silty mudstone & 0.15 & 10 & V \\
Sand-mudstone interlayer & 0.35 & 25 & IV \\
Fine sandstone & 0.55 & 50 & III \\
\hline
\end{tabular}

Due to the development of cracks in the field, the mechanical parameters measured by the samples prepared in the laboratory cannot directly reflect the physical and mechanical properties of the rock mass. Therefore, in this paper, the test results of laboratory measurements are reduced based on the integrity coefficient of the rock mass type on site. The mechanical parameters of the rock mass after reduction are shown in Table 6.

\section{Simulation Analysis of Surrounding Rock Stability of Roadway}

4.1. Scheme Design. According to the engineering background, the cross-sectional shape of the roadway is a semicircular arch with a straight wall, the net cross-sectional size is width $\times$ height $=3.72 \mathrm{~m} \times 3.42 \mathrm{~m}$, and the coordinate axis is located at the centre of the model. In order to analyze the distribution law of surrounding rock stress, deformation, and plastic zone after roadway excavation under different lithologic conditions, two schemes were designed for simulation.

(1) Under the condition of a single-rock mass (silty mudstone, sand-mudstone interlayer, or fine sandstone), a total of three models are established. According to engineering geological conditions, the model size is $X \times Y \times Z=60 \mathrm{~m} \times 11 \mathrm{~m} \times 60 \mathrm{~m}$ under the condition of a silty-mudstone rock mass, and the model size is $X \times Y \times Z=60 \mathrm{~m} \times 12 \mathrm{~m} \times 60 \mathrm{~m}$ under the condition of a sand-mudstone interlayer rock mass, and the model size is $X \times Y \times Z=60 \mathrm{~m} \times 14 \mathrm{~m} \times 60 \mathrm{~m}$ under the condition of a fine-sandstone rock mass. The model is shown in Figure 6(a).

(2) Under the condition that the roadway passes through different rock layers (silty mudstone, sandmudstone interlayer, and fine sandstone), the model 
TABle 6: Physical and mechanical parameters of rock mass after reduction.

\begin{tabular}{lccccccc}
\hline Name & $\begin{array}{c}\text { Elastic modulus } \\
(\mathrm{GPa})\end{array}$ & $\begin{array}{c}\text { Poisson's } \\
\text { ratio }\end{array}$ & $\begin{array}{c}\text { Cohesion } \\
(\mathrm{MPa})\end{array}$ & $\begin{array}{c}\text { Density } \\
\left(\mathrm{kg} / \mathrm{m}^{3}\right)\end{array}$ & $\begin{array}{c}\text { Internal friction } \\
\text { angle }\left(^{\circ}\right)\end{array}$ & $\begin{array}{c}\text { Compressive } \\
\text { strength }(\mathrm{MPa})\end{array}$ & $\begin{array}{c}\text { Tensile strength } \\
(\mathrm{MPa})\end{array}$ \\
\hline Silty mudstone & 0.222 & 0.14 & 0.468 & 2190 & 23.99 & 2.079 & 0.215 \\
Sand-mudstone & 0.539 & 0.09 & 1.019 & 2197 & 28.66 & 4.298 & 0.5635 \\
interlayer & 3.707 & 0.23 & 12.345 & 2486 & 31.5 & 40.81 & 2.037 \\
Fine sandstone & & & & & & & \\
\hline
\end{tabular}

size is $X \times Y \times Z=60 \mathrm{~m} \times 37 \mathrm{~m} \times 60 \mathrm{~m}$, and the model is shown in Figure 6(b).

4.2. Boundary Conditions. FLAC ${ }^{3 \mathrm{D}} 5.0$ [22] numerical simulation software was used for simulation analysis, the bottom of the model is fixed, the left and right sides of the model are restrained by displacement, the front and rear of the model are restrained by displacement, and the top of the model is subjected to the overburden load. The burial depth of the silty mudstone is $380 \mathrm{~m}$, the burial depth of the sandmudstone interlayer is $394.2 \mathrm{~m}$, and the burial depth of the fine sandstone is $405 \mathrm{~m}$. Assuming that the weight of the rock mass is $24 \mathrm{kN} / \mathrm{m}^{2}$, it can be calculated that the applied load on top of the silty-mudstone model under a single-rock mass is $9.12 \mathrm{MPa}$, the applied load on top of the sandmudstone interlayer model is $9.46 \mathrm{MPa}$, and the applied load on top of the fine-sandstone model is $9.72 \mathrm{MPa}$.

4.3. Analysis of the Simulation Results for a Single-Rock Mass Type. Two monitoring lines are set on the top and bottom plates and the two sides of the model, and the calculation results are imported into "Tecplot" software for processing. A schematic diagram of the monitoring line layout is shown in Figure 7.

4.3.1. Stress Analysis. The variation laws of the surrounding rock stress along the vertical and horizontal survey lines after tunnel construction under different lithology conditions are shown in Figure 8.

It can be seen that, after the tunnel construction, the vertical stress exhibits stress concentration at the two sides of the tunnel, and the horizontal stress exhibits stress concentration in the roof and floor of the tunnel. When the lithology is silty mudstone, the vertical stress concentration is approximately $14.3 \mathrm{MPa}$ at a location $16.01 \mathrm{~m}$ from the centre of the roadway. The horizontal stress concentration is approximately $11.64 \mathrm{MPa}$ at a location $14.26 \mathrm{~m}$ from the roadway roof toward the roadway centre and approximately $11.08 \mathrm{MPa}$ at a location $13.65 \mathrm{~m}$ from the roadway floor toward the roadway centre. When the lithology is a sand-mudstone interlayer, the vertical stress concentration is approximately $14.65 \mathrm{MPa}$ at a location $11.21 \mathrm{~m}$ from the centre of the roadway. The horizontal stress concentration is approximately $12.46 \mathrm{MPa}$ at a location $9.98 \mathrm{~m}$ from the roadway roof toward the roadway centre and approximately $12.76 \mathrm{MPa}$ at a location $10.67 \mathrm{~m}$ from the roadway floor toward the roadway centre. When the lithology is fine sandstone, the vertical stress concentration is approximately $14.57 \mathrm{MPa}$ at a location $7.51 \mathrm{~m}$ from the centre of the roadway. The horizontal stress concentration is approximately $13.69 \mathrm{MPa}$ at a location $7.61 \mathrm{~m}$ from the roadway roof toward the roadway centre and approximately $13.54 \mathrm{MPa}$ at a location $7.61 \mathrm{~m}$ from the roadway floor toward the roadway centre. It can be seen from the analysis that the horizontal stress on the vertical line and the vertical stress concentration on the horizontal line transfer to the depth of the surrounding rock and gradually weaken with the decrease in the lithologic strength.

4.3.2. Displacement Analysis. The variation laws of surrounding rock displacement along the horizontal and vertical survey lines after tunnel construction under different lithology conditions are shown in Figure 9. After roadway construction, roof subsidence, floor heave, and two sides' shrinkage, the closer the roadway is to the centre of the roadway, the larger the surrounding rock deformation is. When the lithology is silty mudstone, the roof-to-floor convergence of the roadway is $1110.69 \mathrm{~mm}$, and the convergence of the two sides is $1121.49 \mathrm{~mm}$. When the lithology is sand-mudstone interlayer, the roof-to-floor convergence of the roadway is $757.28 \mathrm{~mm}$, and the convergence of the two sides is $689.53 \mathrm{~mm}$. When the lithology is fine sandstone, the roof-to-floor convergence of the roadway is $348.25 \mathrm{~mm}$, and the convergence of the two sides is $343.75 \mathrm{~mm}$. It can be seen from the above analysis that, with the decrease of rock mass strength, the roof-to-floor convergence and the two sides' convergence gradually increase, and the farther away from the roadway centre, the smaller the deformation.

4.3.3. Plastic Zone Analysis. After tunnel construction, the surrounding rock exhibits tensile failure and shear failure. The distribution laws of the surrounding plastic area after tunnel construction under different lithology conditions are shown in Figure 10. The plastic zone area gradually decreases with increasing lithologic strength.

\subsection{Analysis of Multilayer Simulation Results}

4.4.1. Displacement Analysis. Figure 11(a) shows the movement law of roof strata under the condition of passing through multiple strata during tunnel excavation. The roof rock layer deformation is approximately $109.95 \mathrm{~mm}$ at $Y=6.31 \mathrm{~m}$ when the roadway is driven for $3 \mathrm{~m}$, and the roof rock layer deformation is approximately $238.73 \mathrm{~mm}$ at $Y=7.13 \mathrm{~m}$ when the roadway is driven for $6 \mathrm{~m}$. When the roadway is driven for $9 \mathrm{~m}, 12 \mathrm{~m}, 15 \mathrm{~m}, 18 \mathrm{~m}$, and $21 \mathrm{~m}$, the deformation of the roof strata reaches the maximum at $Y=9.75 \mathrm{~m}$, corresponding to deformations of $338.19 \mathrm{~mm}$, 


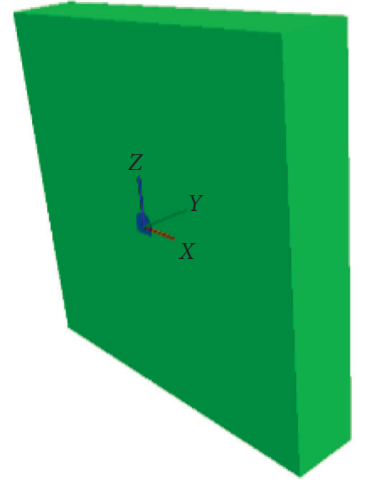

Surrounding rock
Tunnel

(a)

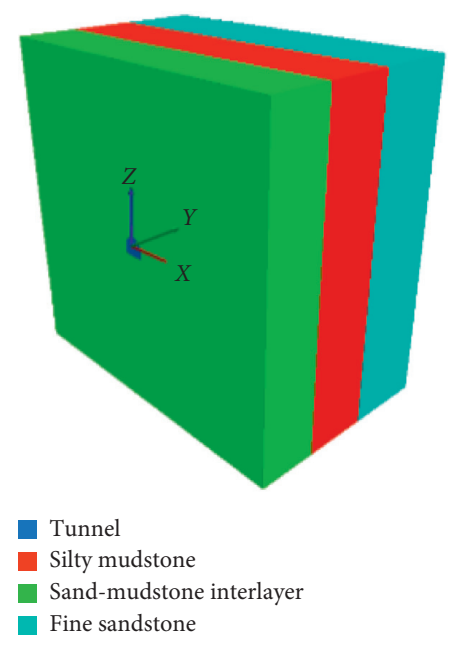

(b)

FIgure 6: Three-dimensional model. (a) Single-rock layer. (b) Multiple-rock layer.

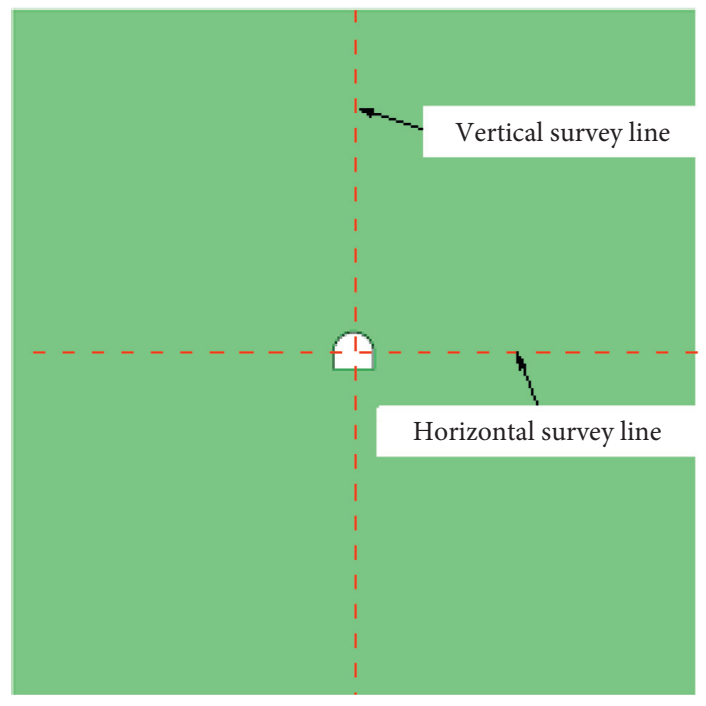

FIGURE 7: Layout of monitoring line.

$423.78 \mathrm{~mm}, 484.31 \mathrm{~mm}, 503.34 \mathrm{~mm}$, and $538.98 \mathrm{~mm}$. When the roadway is driven for $24 \mathrm{~m}$ and $27 \mathrm{~m}$, the deformation of roof strata reaches a maximum at $Y=15.73 \mathrm{~m}$, corresponding to deformations of $547.45 \mathrm{~mm}$ and $567.90 \mathrm{~mm}$, respectively. For the model, in the axial direction ( $Y$ direction), the layer in the range of 0 to $11 \mathrm{~m}$ is the silty mudstone, the layer in the range of 11 to $23 \mathrm{~m}$ is the sand-mudstone interlayer, and the layer in the range of 23 to $37 \mathrm{~m}$ is the fine sandstone. As a result, the roof rock layer fluctuates when the roadway passes through different lithologies, and the roof rock layer at the interface of the silt-mudstone and sand-mudstone interlayer rock layers decreases first and then increases.

4.4.2. Stress Analysis. Figure 11(b) shows the evolution law of the front abutment stress under the condition of crossing multiple rock layers during the tunneling process. The support stress appears in the front and back of the roadway after driving, and the abutment stress moves forward with increasing driving size, forming the movable abutment stress. When the roadway is driven for $3 \mathrm{~m}$, the front abutment stress reaches a maximum of $11.03 \mathrm{MPa}$ at $Y=12.21 \mathrm{~m}$; when the roadway is driven for $6 \mathrm{~m}$, the front abutment stress reaches a maximum of $11.65 \mathrm{MPa}$ at $Y=14.24 \mathrm{~m}$; when the roadway is driven for $9 \mathrm{~m}$, the front abutment stress reaches a maximum of $12.01 \mathrm{MPa}$ at $Y=17.23 \mathrm{~m}$; when the roadway is driven for $12 \mathrm{~m}$, the front abutment stress reaches a maximum of $12.27 \mathrm{MPa}$ at $Y=19.90 \mathrm{~m}$; when the roadway is driven for $15 \mathrm{~m}$, the front abutment stress reaches a maximum of $12.72 \mathrm{MPa}$ at $Y=23.19 \mathrm{~m}$; when the roadway is driven for $18 \mathrm{~m}$, the front abutment stress reaches a maximum of $12.85 \mathrm{MPa}$ at $Y=26.25 \mathrm{~m}$; when the roadway is driven for $21 \mathrm{~m}$, the front abutment stress reaches a maximum of $12.84 \mathrm{MPa}$ at $Y=28.88 \mathrm{~m}$; when the roadway is driven for $24 \mathrm{~m}$, the front abutment stress reaches a maximum of $12.95 \mathrm{MPa}$ at 


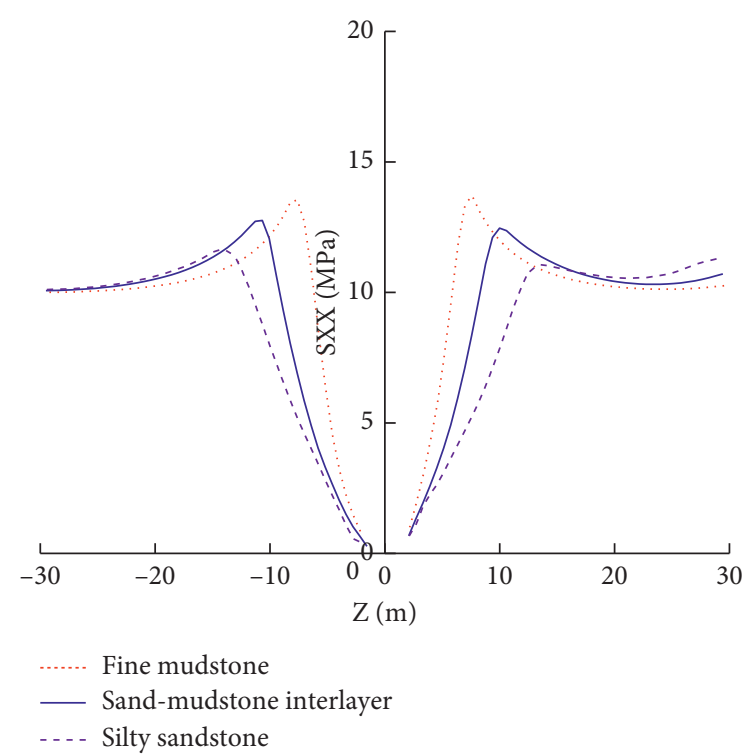

(a)

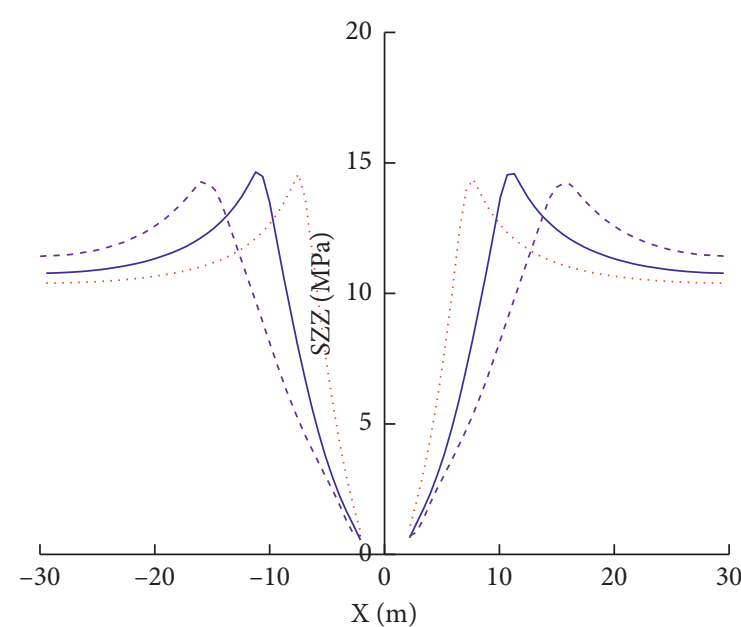

...... Fine mudstone

— Sand-mudstone interlayer

-. - - Silty sandstone

FIGURE 8: Distribution law of stress on monitoring line under different lithology conditions. (a) Vertical survey line. (b) Horizontal survey line.

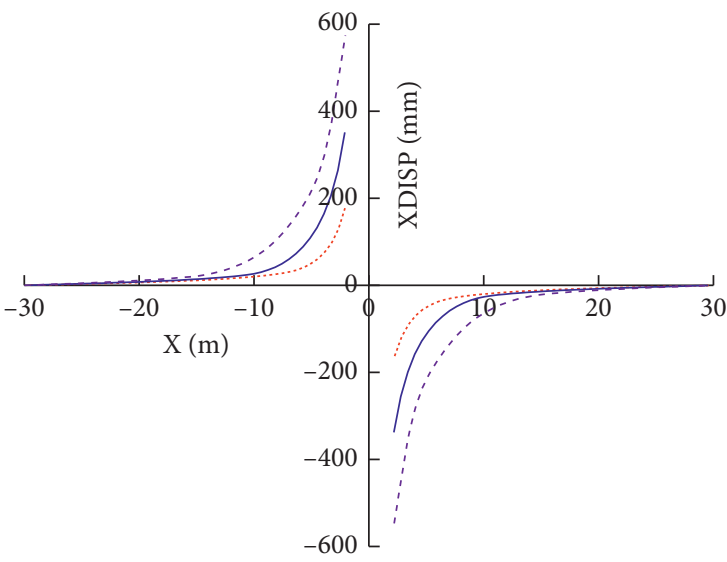

Fine mudstone

- Sand-mudstone interlayer

-..- Silty sandstone

(a)

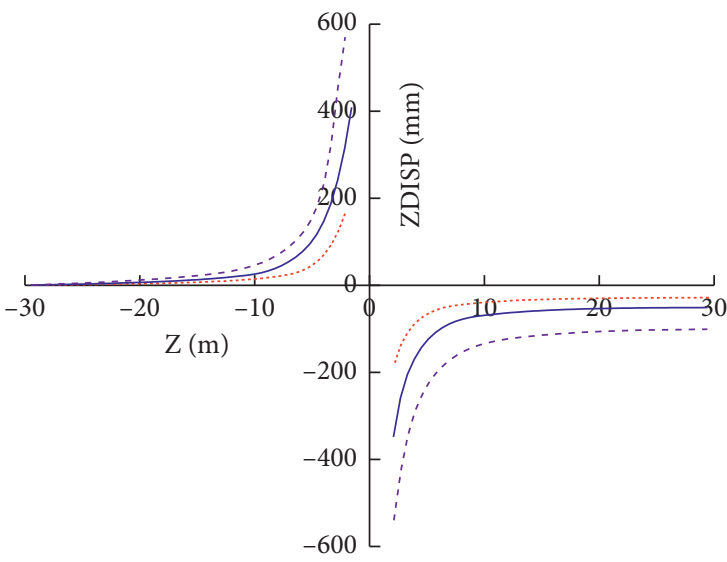

Fine mudstone

— Sand-mudstone interlayer

... - Silty sandstone

Figure 9: Distribution laws of displacement on the monitoring line under different lithology conditions. (a) Vertical survey line. (b) Horizontal survey line.
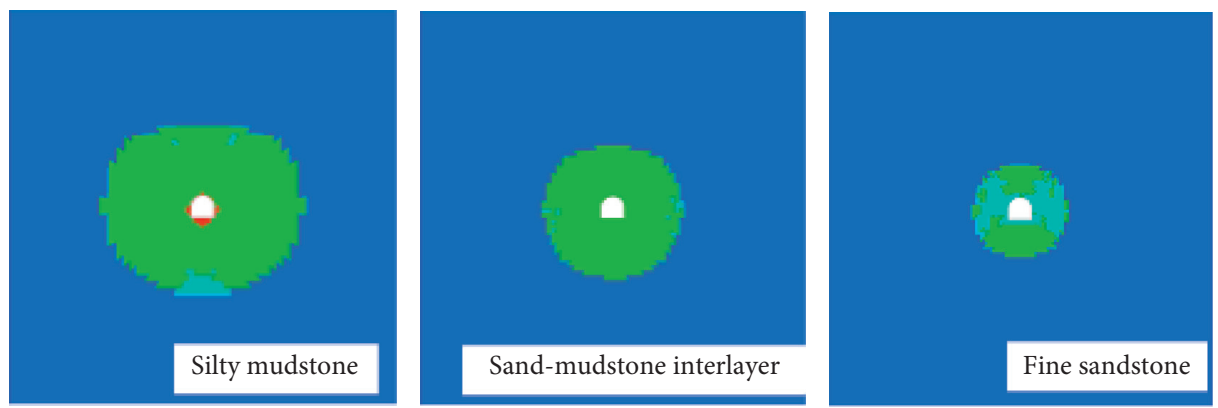

None

Shear-n shear- $\mathrm{p}$

Shear-n shear-p tension-p
Shear-p

Shear-p tension-p

FIgURE 10: Distribution laws of the plastic zone of the surrounding rock under different lithology conditions. 


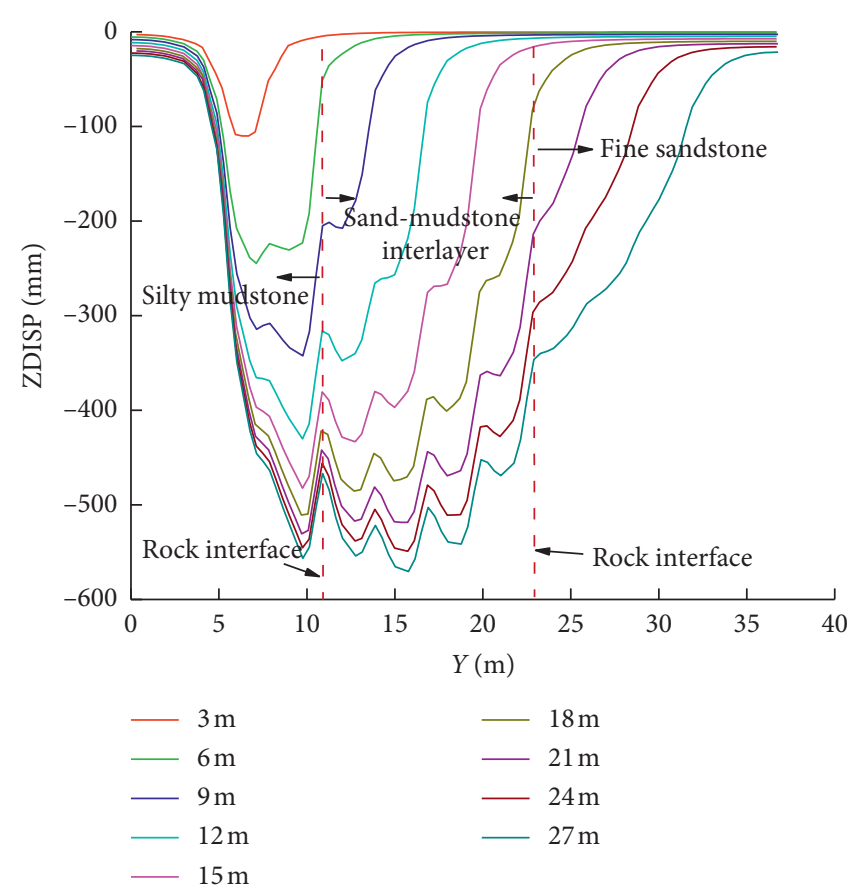

(a)

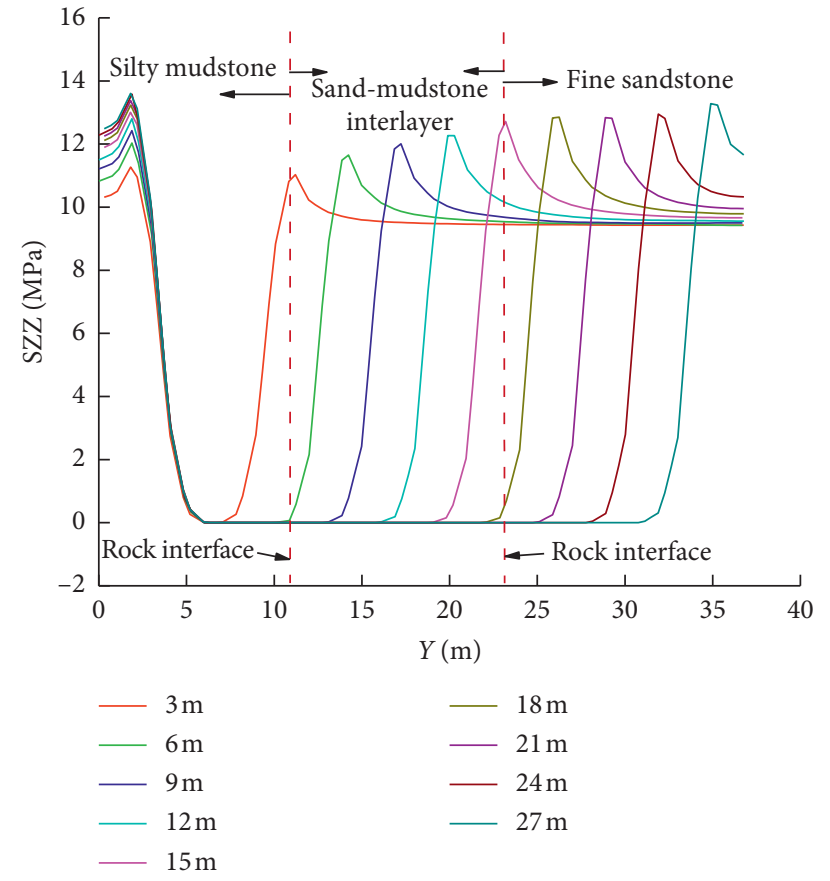

(b)

Figure 11: Movement law of roof strata and the evolution law of abutment stress in front of and behind the roadway. (a) Movement law of roof strata. (b) Evolution law of abutment stress.

$Y=31.90 \mathrm{~m}$; when the roadway is driven for $27 \mathrm{~m}$, the front abutment stress reaches a maximum of $13.28 \mathrm{MPa}$ at $Y=34.90 \mathrm{~m}$. These results are shown in Figure 11(b).

4.4.3. Plastic Zone Analysis. The distribution laws of the plastic zone around the surrounding rock under different sizes of roadway driving are shown in Figure 12. After tunnel construction, the surrounding rock exhibits shear and tensile failure. With increasing driving size, the scope of the plastic zone around the tunnel gradually increases. However, due to the different lithologies, the range of the plastic zone is different in different lithology regions.

In order to more vividly show the failure characteristics of surrounding rock around the roadway, write fish statement to extract the number of unit failure of surrounding rock around the roadway, and draw as shown in Figure 13. Shear and tensile failure occur in the surrounding rock after tunnel excavation, and the number of shear-now units and shearpast units is far greater than that of tension-past units, but there are no tension-now units. With the increase in tunnel driving size, the number of shear-now and shear-past elements increases linearly, while the number of tension-past elements is small and first increases and then decreases slowly.

\section{Instability Mechanism of Surrounding Rock and Surrounding Rock Control Technology and Application in a Fracture Zone}

5.1. Deformation and Failure Mechanism. From the deformation and failure characteristics of the roadway, it can be seen that the existing support form of the Xinyi Coal Mine has difficulty meeting the functional requirements of the roadway and that the support means adopted cannot effectively control the continuous deformation of the surrounding rock of the roadway. The mechanism of roadway instability is as follows:

(1) Fractures develop in the surrounding rock. The surrounding rocks in the tectonic area are subject to tension and compression due to the fault activity, cracks develop, the surrounding rock becomes broken, and the self-stabilizing ability is poor.

(2) Surrounding rock has poor lithologic strength and undergoes cementation. The fault zone is mainly composed of fault mud and argillaceous rocks. These rocks are greatly affected by water: when in contact with water, they expand and swell, have strong softening properties, sharply decrease in strength, and lose bearing capacity.

(3) Gush of water. The sandstone water at the top and bottom of the Xinyi Coal Mine is a weak aquifer. The fissure water is controlled by the development degree of fissures and structures, which clearly varies among different sections. The fissure water is static reserve water, but the water pouring into the roadway is closely followed by changes in the hydraulic head, which cause certain inconveniences during the construction.

(4) The strength of the original support system is low. The original support mostly used an anchor rod with a length of $1.8 \mathrm{~m}$, and the pretightening force could not be applied in time, resulting in premature separation and deformation of the surrounding rock. 

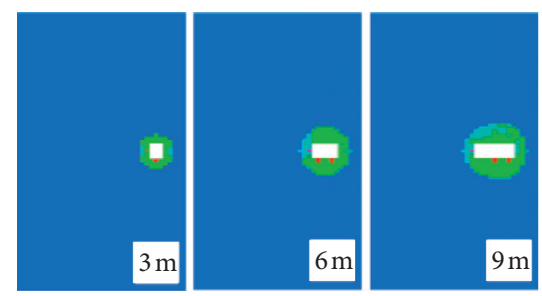

None

Shear-n shear-p

Shear-n shear-p tension-p
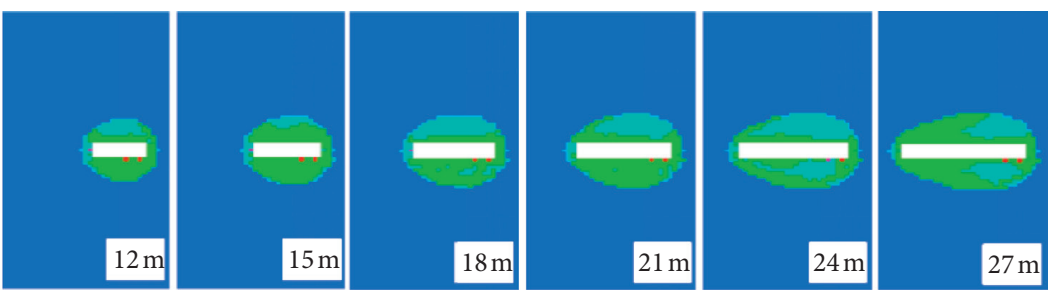

Shear-p

Shear-p tension-p

FIgURE 12: Distribution law of plastic zone.

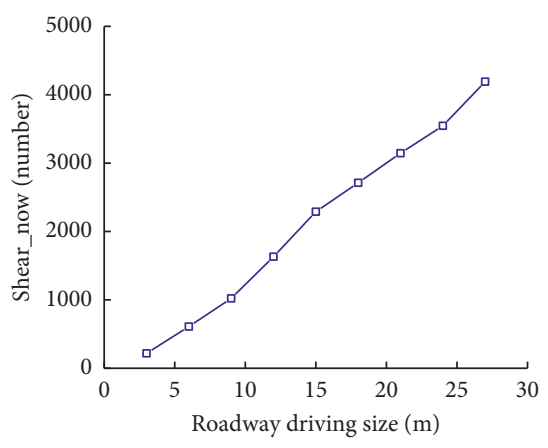

(a)

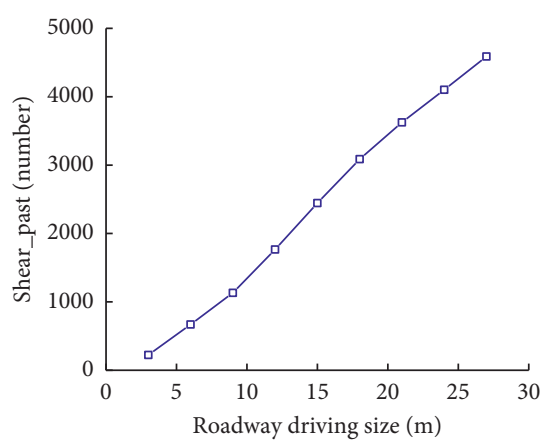

(b)

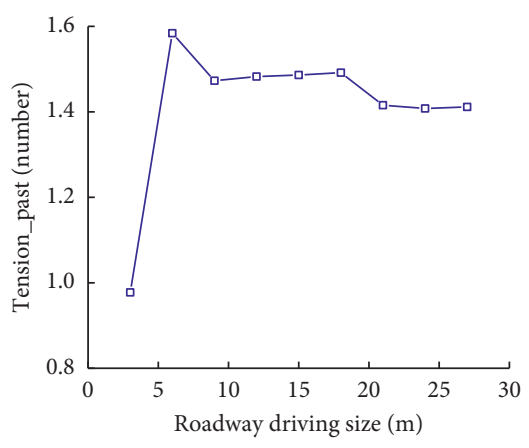

(c)

Figure 13: The number of surrounding rock failure units in the process of roadway excavation. (a) Shear-now. (b) Shear-past. (c) Tensionpast.

(5) Rheological changes of the rock surrounding the roadway. The initial support form of the surrounding rock of the roadway is anchor shotcrete support, but, due to untimely spraying, weathering and even loosening of the surrounding rock may easily cause failure of the anchor rod and make the support structure unstable. Under the action of high stress and fault tectonic stress, the surrounding rock of the roadway undergoes rheological changes.

5.2. Control Technology and Parameters. Based on the above analysis, the form of closed support + shotcrete + grouting + anchor mesh cable coupling support is proposed. Steel support can prevent the collapse of broken surrounding rock, shotcrete can seal the surrounding rock and prevent the weathering of the surrounding rock surface, and grouting can improve the self-bearing capacity of the surrounding rock and enhance the anchoring effect of the anchor bolt; a bottom arch beam can control the floor heave; a steel support and an anchor cable can be coupled through a structural compensation anchor cable to control the deformation of the surrounding rock and fully utilize the advantages of active and passive support. The construction process is as follows: driving section $\longrightarrow$ temporary support $\longrightarrow$ installation of anchor bolt $\longrightarrow$ initial shotcreting $30 \mathrm{~mm} \longrightarrow$ installation of U-shaped steel support $\longrightarrow$ installation of anchor cable $\longrightarrow$ shotcreting to a given thickness of $150 \mathrm{~mm} \longrightarrow$ installation of grouting anchor bolt $\longrightarrow$ grouting. The support design drawing is shown in Figure 14.

(1) Anchor rod parameters. A high-strength left-handed nonsteel rib steel anchor with a diameter of $22 \mathrm{~mm}$ and length of $2400 \mathrm{~mm}$, two Z2350 resin cartridges with an anchor length of $1200 \mathrm{~mm}$, row spacing between anchors of $700 \times 700 \mathrm{~mm}$, and anchor pretightening force of at least $150 \mathrm{kN}$ was adopted. The torque force applied by the anchor nut is at least $132 \mathrm{Nm}$, the anchor is perpendicular to the wall of the roadway, the foot is installed $15^{\circ}$ to the wall of the roadway, the yield strength is $400 \mathrm{MPa}$, and the tensile strength is $500 \mathrm{MPa}$.

(2) Anchor cable parameters. Seven strands of highstrength relaxation steel wire anchor cable with diameter of $17.8 \mathrm{~mm}$ and length of $6500 \mathrm{~mm}$ are used, and four coils of Z2350 resin cartridge are used for anchoring. The anchorage length is $2000 \mathrm{~mm}$, the row spacing between anchors is $1400 \times 1400 \mathrm{~mm}$, and the anchor pretightening force is not less than $200 \mathrm{kN}$.

(3) Shotcrete parameters. The strength is not less than C25, cement : sand : gravel $:$ water $=1: 1.94: 2.79$ :

0.49 , medium coarse sand, gravel diameter: $5 \sim 7 \mathrm{~mm}$, accelerator model is $\mathrm{J85}$, the mixing amount is generally $2 \sim 4 \%$ of the cement weight, the upper limit of shotcrete arch is taken, the accelerator must be evenly added at the feeding port of the shotcrete 


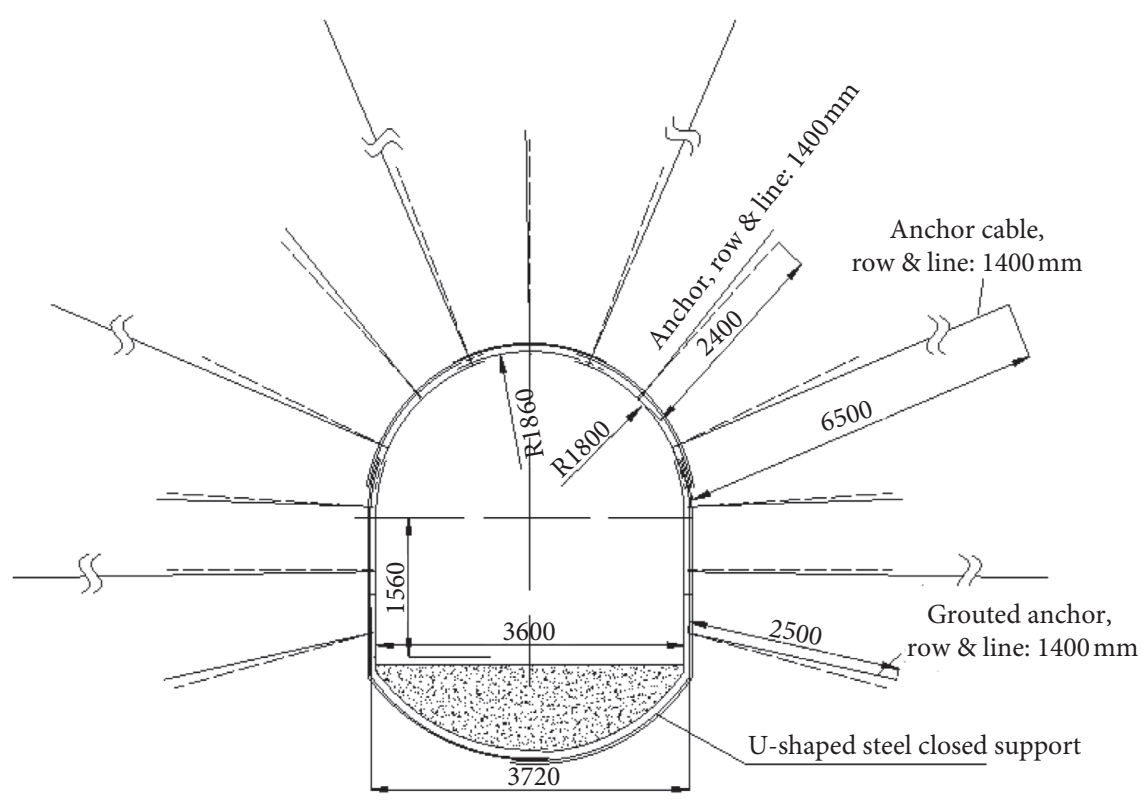

FIGURE 14: Roadway support design drawing.

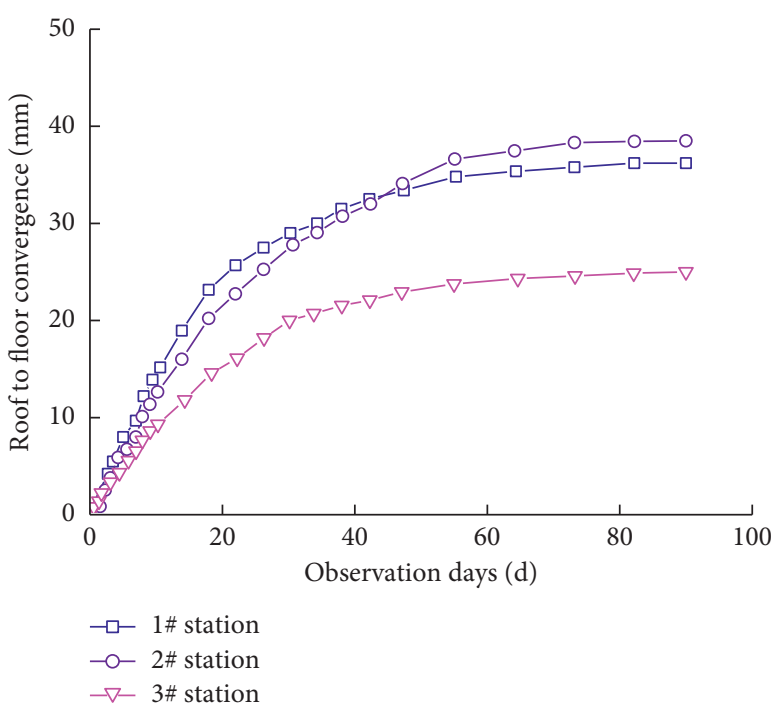

(a)

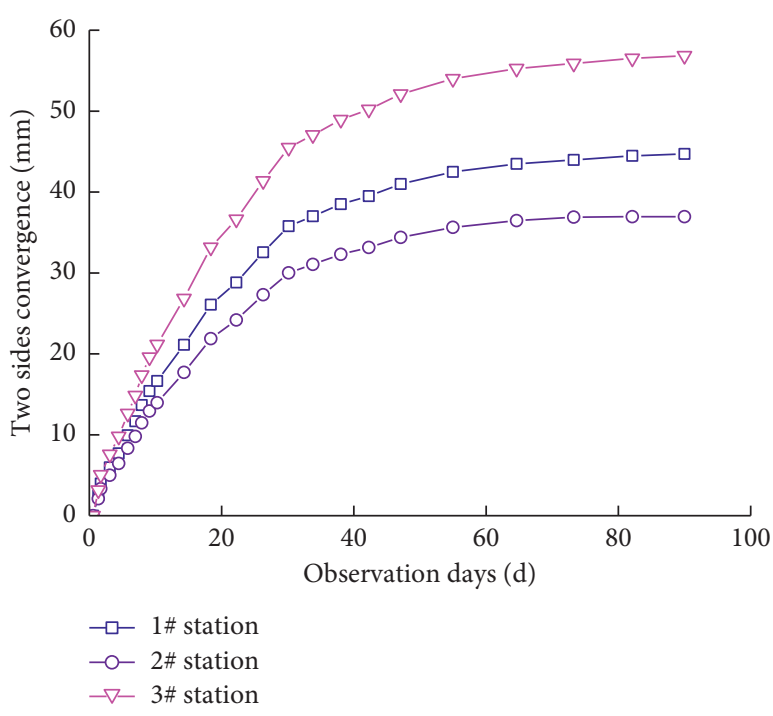

(b)

FIgURE15: Relationship curve of roadway deformation with time. (a) Roof-to-floor convergence. (b) Two sides' convergence.

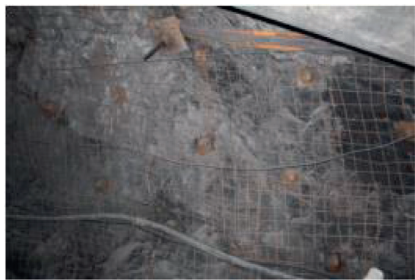

(a)

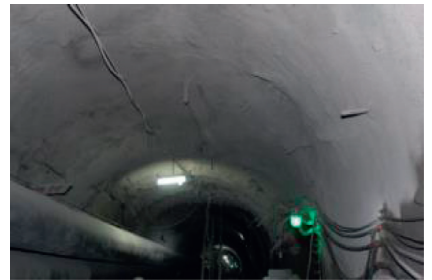

(b)

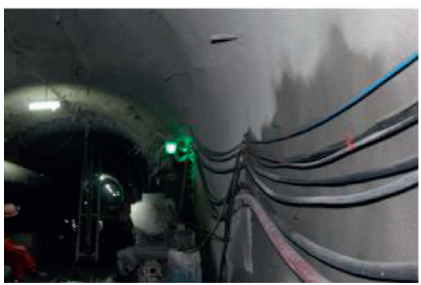

(c)

FIGURE 16: Displacement monitoring results of the surrounding rock around roadway. 
machine, and the total thickness of each section of the spraying layer is $150 \mathrm{~mm}$.

(4) Grouting parameters. The grouting material is cement-water glass single-liquid slurry using slag Portland cement, and the water:cement ratio is $0.75: 1.525$. Using a grouting tube with a diameter of $22 \mathrm{~mm}$ and a length of $2500 \mathrm{~mm}$, the grouting volume of a single hole is $1 \sim 1.5 \mathrm{~m}^{3}$, the grouting pressure is $0.1 \sim 1.5 \mathrm{MPa}$, the grouting flow is $3.0 \sim 3.5 \mathrm{~m}^{3} / \mathrm{h}$, and the spacing between the grouting holes is $1600 \mathrm{~mm} \times 1600 \mathrm{~mm}$.

(5) U-shaped steel closed bracket. U36 steel: the row spacing of the bracket is $1400 \mathrm{~mm}$, and the thickness of the spray gun is $150 \mathrm{~mm}$.

5.3. Deformation Monitoring. After adopting new support measures, a displacement observation station was set up on the south wing concentrated track, and a total of three roadway surface surrounding rock stations were arranged at a $10 \mathrm{~m}$ spacing along the fault fracture zone. The homemade observation stand and laser rangefinder were used for observation, and the curve of roadway deformation with time was drawn, as shown in Figure 15.

Figure 15(a) shows that the roof-to-floor convergence of the roadway is $35 \mathrm{~mm}, 38 \mathrm{~mm}$, and $25 \mathrm{~mm}$ within 100 days of observation. From Figure 15(b), the convergence of the two sides of the roadway is $45 \mathrm{~mm}, 37 \mathrm{~mm}$, and $56 \mathrm{~mm}$ within 100 days of observation. The overall reinforcement effect of the roadway is good, and the roadway after the new support measures is shown in Figure 16. The surface of the roadway is smooth, and there is no phenomenon of concrete cracking or anchor fracture.

\section{Conclusion}

(1) The rock blocks were collected on site at the fracture zone, and remoulded samples were prepared for mechanical experiments in the laboratory. The basic mechanical parameters of the roadway passing through silty mudstone, sand-mudstone interlayer, and fine sandstone were analyzed.

(2) A three-dimensional model was established to analyze the distribution of stress, deformation, and plastic area in the surrounding rock mass after the tunnel passes through, considering both a singlerock mass and a multilayer-rock mass.

(3) We proposed the "closed support + shotcrete + grouting + anchor mesh cable coupling support form" and arranged the observation station in the field for deformation monitoring. It is found that the deformation of the roof, floor, and two sides of the roadway is small, the roadway surface is smooth, and the overall reinforcement effect is good.

\section{Data Availability}

The data used to support the finding of this study have not been made available because research projects is in pregress.

\section{Conflicts of Interest}

The authors declare no conflicts of interest.

\section{Acknowledgments}

This work was supported by the Research Fund of State and Local Joint Engineering Laboratory for Gas Drainage \& Ground Control of Deep Mines (Henan Polytechnic University) (no. SJF202004), Doctoral Research Initiation Fund of Huaiyin Institute of Technology (no. Z301B20536), Jiangsu Provincial Department of Housing and Urban Rural Development Project (no. Z413B19341), and the National Natural Science Foundation of China (no. 51974104).

\section{References}

[1] Q. S. Liu, W. Zhang, X. L. Lu et al., "Safety monitoring and stability analysis of large-scale roadway in fault fracture zone," Chinese Journal of Rock Mechanics and Engineering, vol. 29, no. 10, pp. 1954-1962, 2010.

[2] X. Y. Wang, J. B. Bai, L. Li et al., "Deformation failure mechanism and control technology of mining-induced roadway near a fault," Journal of Mining \& Safety Engineering, vol. 31, no. 5, pp. 674-680, 2014.

[3] S. J. Wei, H. Nan, and Y. H. Xu, "Study on instability mechanism and control technology of mine roadway in continued breaking region," Coal Science and Technology, vol. 44, no. 04, pp. 39-44, 2016.

[4] X. X. Chen and J. P. Wu, "Study on the mechanism and control technology of large deformation of roadway surrounding rock in the fault fracture zone," Journal of Mining \& Safety Engineering, vol. 35, no. 5, pp. 13-20, 2018.

[5] N. Zhang, X. L. Xu, Z. F. Cheng et al., "Geological guarantee and construction controlling technique of main roadway crossing fault zone with $435 \mathrm{~m}$ fall," Chinese Journal of Rock Mechanics and Engineering, vol. 27, no. S1, pp. 3292-3297, 2008.

[6] T. Q. Xiao, J. B. Bai, J. P. Li et al., "Stabilization mechanism of crushed surrounding rock in coal roadway with bolt support near fault," Journal of Mining \& Safety Engineering, vol. 27, no. 4, pp. 40-44, 2010.

[7] Y. X. Zhao, Y. D. Jiang, L. Meng et al., "Supporting technique with advanced pipe-shed grouting in extremely complicated faulting zone," Journal of Mining \& Safety Engineering, vol. 30, no. 2, pp. 262-266, 2013.

[8] Q. Wang, S. C. Li, Z. Li et al., "Analysis of roof collapse mechanism and supporting measures in fault zone of coal roadway," Rock and Soil Mechanics, vol. 33, no. 10, pp. 3093-3102, 2012.

[9] Y. X. Hao, J. Wang, H. Wang et al., "Coupled bolt-meshanchor supporting technology for deep fault fracture zones throughout layers soft rock roadway," Journal of Mining \& Safety Engineering, vol. 33, no. 2, pp. 45-51, 2016.

[10] Y. W. Zhang, "Study on support system optimization of broken seam and rock gateway along fault," Coal Science and Technology, vol. 44, no. 9, pp. 72-76, 2016.

[11] S. Yan, J. B. Bai, Z. Z. Zhang et al., "Failure mechanism and ground control of a main entry above aquifers crossing fault zone," Journal of Mining \& Safety Engineering, vol. 33, no. 6, pp. 979-984, 2016.

[12] Q. B. Meng, L. J. Han, B. Qi et al., "Study and application of key technology for roadway crossing faults under complex 
geological conditions," Journal of Mining \& Safety Engineering, vol. 34, no. 2, pp. 199-207, 2017.

[13] W. H. Song, M. Z. Shi, C. Y. Zhao et al., "Study on fracture zone of cross fault group in large section rectangular roadway under mining conditions," Coal Science and Technology, vol. 46, no. 10, pp. 122-129, 2018.

[14] J. Wang, C. C. Hu, J. P. Zuo et al., "Mechanism of roadway floor heave and control technology in fault fracture zone," Journal of China Coal Society, vol. 44, no. 02, pp. 53-64, 2019.

[15] H. P Kang, M. J Fan, F. Q. Gao et al., "Deformation and support of rock roadway at depth more than 1000 meters," Chinese Journal of Rock Mechanics and Engineering, vol. 34, no. 11, pp. 2227-2241, 2015.

[16] H. J. Jia and H. Wang, "Principle and application of the double cacheable and gradually deformable supporting shells for soft rock tunneling," Rock and Soil Mechanics, vol. 36, no. 4, pp. 1119-1126, 2015.

[17] Q. B. Meng, L. J. Han, F. K. Zhang et al., "Coupling support effect on high-stress deep soft rock roadway and its application," Rock and Soil Mechanics, vol. 38, no. 5, pp. 1424-1444, 2017.

[18] F. L. He and G. C. Zhang, "Analysis and control of stability of the fractured soft rock surrounding a deep roadway," Rock and Soil Mechanics, vol. 36, no. 5, pp. 1397-1406, 2015.

[19] Y. Li, L. Yuan, G. X. Liu et al., "Determination of failure zone and support pressure of circular roadway under deep mining," Rock and Soil Mechanics, vol. 35, no. 1, pp. 226-231, 2014.

[20] S. C. Wu, M. Zhang, and S. H. Zhang, "Study on the determination method of the instantaneous mohr-coulomb strength parameters of a modified hoek-brown failure criterion," Rock and Soil Mechanics, vol. 40, no. 11, pp. 1-14, 2019.

[21] K. Y. Wang and D. Q. Xu, "Application of quantitative GSI in the estimation of rock mechanics parameters," Journal of Railway Science and Engineering, vol. 13, no. 11, pp. 21682173, 2016.

[22] T. Wang, FLAC3D Numerical Simulation Method and Engineering Application, China Construction Industry Press, Beijing, China, 2015. 